\title{
REVIEW
}

\section{Dengue vaccine: an update on recombinant subunit strategies}

\author{
J. MARTIN, L. HERMIDA
}

Center for Genetic Engineering and Biotechnology (CIGB), Ave 31, P.O. Box 6162, Havana 6, 10 600, Cuba

Received May 28, 2015; accepted February 1, 2016

\begin{abstract}
Summary. - Dengue is an increasing public health problem worldwide, with the four serotypes of the virus infecting over 390 million people annually. There is no specific treatment or antiviral drug for dengue, and prevention is largely limited to controlling the mosquito vectors or disrupting the human-vector contact. Despite the considerable progress made in recent years, an effective vaccine against the virus is not yet available. The development of a dengue vaccine has been hampered by many unique challenges, including the need to ensure the absence of vaccine-induced enhanced severity of disease. Recombinant protein subunit vaccines offer a safer alternative to other vaccine approaches. Several subunit vaccine candidates are presently under development, based on different structural and non-structural proteins of the virus. Novel adjuvants or immunopotentiating strategies are also being tested to improve their immunogenicity. This review summarizes the current status and development trends of subunit dengue vaccines.
\end{abstract}

Keywords: dengue; vaccine; subunit; recombinant protein

\section{Contents:}

1. Introduction

2. Envelope protein-based vaccines

2.1 Truncated E protein

2.2 Virus-like particles

2.3 Domain III-based fusion proteins

2.3.1 Domain III-P64k protein

2.3.2 Domain III-dengue virus capsid protein

2.3.3 Domain III-STF2

2.3.4 Domain III-hepatitis B core antigen

2.3.5 Domain II-domain III-NS1 fusion protein

2.3.6 Domain III-DEC-205

2.3.7 DERIC

E-mail: jmartinmach@gmail.com; phone: +53-7-2716022. Abbreviations: $\mathrm{ADE}=$ antibody-dependent enhancement of infection; DV = dengue virus; LAV = live attenuated virus; ODN = oligodeoxynucleotide; $\mathrm{VLP}=$ virus-like particles; $\mathrm{RIC}=$ recombinant immune complexes; STF2 = Salmonella enterica serovar Typhimurium FljB flagellin phase 2
2.3.8 Lipidated domain III

2.3.9 Bivalent or tetravalent domain III

3. Non-structural protein-based vaccines

3.1 NS1

3.2 NS3

4. Capsid protein-based vaccine

5. Conclusions

\section{Introduction}

Dengue is the leading arthropod-borne viral disease worldwide and is caused by dengue virus (DV), a member of the genus Flavivirus. It is estimated that 390 million DV infections occur annually in the world, of which 96 million are apparent. Moreover, 3.6 billion people live in areas at risk of DV transmission (Bhatt et al., 2013). Infection with one of the four DV serotypes (DV1-4) can cause a broad spectrum of clinical manifestations, ranging from asymptomatic to self-limited febrile illness, dengue fever, to the life-threatening dengue hemorrhagic fever/dengue 
shock syndrome (WHO, 2009). Dengue virus contains a positive-sense single-stranded RNA genome encoding three structural (C, prM and $\mathrm{E}$ ), and seven nonstructural (NS1, NS2A, NS2B, NS3, NS4A, NS4B, and NS5) proteins (Chambers et al., 1990).

The widespread geographical distribution of the DVtransmitting mosquitoes and the potentially severe symptoms associated with DV infection make the development of a vaccine an urgent need. However, no licensed vaccine or antiviral drug is still available after more than 70 years of efforts (Gubler, 2011). Current vaccine candidates under development include live attenuated virus vaccines, live recombinant viral-vector vaccines, inactivated virus vaccines, DNA vaccines and recombinant protein vaccines. The most advanced DV vaccines to date are live attenuated virus (LAV) vaccines. These have several advantages like mimicking natural infection, inducing potent humoral and cellular responses, and conferring long-lasting immune memory (Pulendran and Ahmed, 2011). Recently, the Sanofi Pasteur chimeric yellow fever 17D-DV-1 to -4 CYD tetravalent dengue vaccine (CYD-TDV) had an efficacy of $56.5 \%$ and $60.8 \%$ in phase III clinical trials in Asia and Latin America, respectively (Capeding et al., 2014; Villar et al., 2015). Although these results are encouraging, there are still some concerns regarding the safety of replicating vaccines. Live attenuated vaccine candidates face the challenge of maintaining the balance between safe attenuation and robust immunogenicity. Viral interference among the monovalent components has been observed in preclinical and clinical settings (Kitchener et al., 2006; Guy et al., 2009) and can lead to immune imbalance with the potential risk of undesirable immunopathogenic responses (Webster et al., 2009). Therefore, lengthy immunization regimens may be required to induce immune responses against all four serotypes.

Recombinant protein vaccine candidates may offer significant advantages over other approaches. Subunit vaccines can be used in accelerated schedules. In addition, they are safer and easier to produce and administer than vaccines containing live pathogens (Peek et al., 2008). However, subunit vaccines often require multiple doses and the use of adjuvants in order to elicit robust immune responses (Hansson et al., 2000). Several strategies are currently under development to overcome these drawbacks. Here we review the latest progress in the development of recombinant protein vaccines against dengue.

\section{Envelope protein-based vaccines}

The dengue envelope (E) glycoprotein is responsible for viral attachment to host cells and the low $\mathrm{pH}$ fusion of viral and host cell membranes (Rey et al., 1995). It is also the main target of neutralizing antibodies (Roehrig et al., 1998).
Each E protein monomer has three domains: DI, DII, and DIII (Zhang et al., 2004). Much research aiming to create a subunit vaccine against dengue has been focused on the $\mathrm{E}$ protein, with approaches including the truncated $\mathrm{E}$ antigen, virus-like particles containing the pre-membrane (prM) and E proteins, or fusion proteins based on the domain III of the E protein (Table 1).

\subsection{Truncated E protein}

Hawaii Biotech Inc. developed a recombinant subunit vaccine candidate containing $80 \%$ of the dengue virus envelope protein (DEN-80E). The C-terminal truncation of the E protein at amino acid 395 (393 for DEN3) removes the membrane anchor sequence, favoring protein expression and native-like folding (Coller et al., 2011). Glycosylated antigens were produced at high levels using the Drosophila S2 cell expression system.

The DEN2-80E subunit candidate induced neutralizing antibodies and partially protected rhesus macaques after two doses administered with five different adjuvants (AS04-OH, AS04-PO, AS05, AS08 or alum) (Putnak et al., 2005). When formulated with the saponin-based adjuvant ISCOMATRIX ${ }^{\mathrm{m}}$, DEN2-80E elicited a potent neutralizing antibody response in mice that persisted for at least 6 months (Clements et al., 2010). Immunization of mice with the individual monovalent candidates or the tetravalent mixture in ISCOMATRIX ${ }^{\mathrm{min}}$ resulted in similar neutralizing antibody titers against homologous DV serotypes.

A tetravalent DEN-80E subunit vaccine was also assessed in a small study using two monkeys per group. The DV2 non-structural protein 1 (NS1), produced in Drosophila S2 cells, was included in the formulation to enhance immunogenicity. Low doses of the recombinant proteins induced neutralizing antibodies against the four viral serotypes and protected monkeys against challenge with DV2 or DV4 (Clements et al., 2010).

A phase 1 placebo-controlled, double-blind trial studied the safety of the monovalent DV1-80E candidate in 16 flavivirus-naive healthy adults, who received three monthly intramuscular doses of 10 or $50 \mu \mathrm{g}$ of the vaccine in aluminum hydroxide (Manoff et al., 2015). Both formulations were generally well tolerated and induced neutralizing antibodies in the majority of subjects, but titers in most subjects were modest and waned over time.

Following acquisition of the Hawaii Biotech dengue program by Merck \& Co. in 2010, a phase 1 trial with a tetravalent formulation of the vaccine candidate (renamed V180) has recently completed enrollment in Australia (Clinicaltrials.gov NCT01477580). The study will compare the safety and immunogenicity of three doses of V180 (at 1-month intervals) formulated with low or mid dose ISCOMATRIX ${ }^{\mathrm{mw}}$ adjuvant, alum or without adjuvants. 
Table 1. Current status of recombinant subunit dengue vaccine development

\begin{tabular}{|c|c|c|c|}
\hline Vaccine approach & Description & Status & References \\
\hline Truncated E protein & $\begin{array}{l}\text { Tetravalent truncated ( } 80 \%) \text { recom- } \\
\text { binant E protein (DEN-80E) expressed } \\
\text { in Drosophila S2 cells }\end{array}$ & $\begin{array}{l}\text { DV } 1 \text { monovalent phase } 1 \text { trial complet- } \\
\text { ed; tetravalent phase } 1 \text { trial completed } \\
\text { enrollment }\end{array}$ & $\begin{array}{l}\text { [Clements et al., 2010; Manoff et al., } \\
\text { 2015; Putnak et al., 2005] }\end{array}$ \\
\hline \multirow[t]{3}{*}{ Virus-like particles } & $\begin{array}{l}\text { prM/E VLP expressed in Pichia pastoris } \\
\text { and } 293 \mathrm{~T} \text { cells }\end{array}$ & $\begin{array}{l}\text { Tetravalent candidate evaluated in } \\
\text { mice }\end{array}$ & [Liu et al., 2014; Zhang et al., 2011] \\
\hline & $\begin{array}{l}\mathrm{prM} / \mathrm{E} \text { VLP expressed in insect cells } \\
\text { (Sf9) }\end{array}$ & $\begin{array}{l}\text { Monovalent DV1 and DV2 candidates } \\
\text { evaluated in mice }\end{array}$ & [Kuwahara et al., 2010] \\
\hline & E VLP expressed in $P$. pastoris & $\begin{array}{l}\text { Monovalent DV2 candidate evaluated } \\
\text { in mice }\end{array}$ & [Mani et al., 2013] \\
\hline \multirow[t]{12}{*}{$\begin{array}{l}\text { Domain III-based } \\
\text { fusion proteins }\end{array}$} & $\begin{array}{l}\text { EDIII-P64k fusion proteins expressed in } \\
\text { Escherichia coli }\end{array}$ & $\begin{array}{l}\text { Tetravalent candidate evaluated in mice; } \\
\text { monovalent DV1 and DV2 candidates } \\
\text { evaluated in NHPs }\end{array}$ & $\begin{array}{l}\text { [Bernardo et al., 2008; Hermida et al., } \\
\text { 2006; Lazo et al., 2014; Valdés et al., } \\
\text { 2009a] }\end{array}$ \\
\hline & $\begin{array}{l}\text { EDIII-capsid fusion protein (DIIIC) } \\
\text { expressed in E. coli }\end{array}$ & $\begin{array}{l}\text { Monovalent DV2 candidate evaluated } \\
\text { in NHPs }\end{array}$ & $\begin{array}{l}\text { [Gil et al., 2015; Suzarte et al., 2014; } \\
\text { Valdés et al., 2009b; Zuest et al., 2015] }\end{array}$ \\
\hline & $\begin{array}{l}\text { Tetravalent EDIII-STF2 fusion proteins } \\
\text { expressed in E. coli }\end{array}$ & $\begin{array}{l}\text { Tetravalent candidate evaluated in mice } \\
\text { and NHPs }\end{array}$ & [Liu et al., 2015] \\
\hline & $\begin{array}{l}\text { EDIII-HBcAg fusion protein expressed } \\
\text { in } P \text {. pastoris }\end{array}$ & $\begin{array}{l}\text { Monovalent DV2 candidate evaluated } \\
\text { in mice }\end{array}$ & [Arora et al., 2013] \\
\hline & $\begin{array}{l}\text { Recombinant EDII-EDIII-NS1 fusion } \\
\text { protein expressed in Drosophila S2 }\end{array}$ & $\begin{array}{l}\text { Monovalent DV2 candidate evaluated } \\
\text { in mice }\end{array}$ & $\begin{array}{l}\text { [Garcia-Machorro et al., 2013; Mellado- } \\
\text { Sánchez et al., 2010] }\end{array}$ \\
\hline & $\begin{array}{l}\text { scFvDEC205-EDIII expressed in Nico- } \\
\text { tiana benthamiana }\end{array}$ & $\begin{array}{l}\text { Monovalent DV2 candidate evaluated } \\
\text { in mice }\end{array}$ & [Coconi-Linares et al., 2013] \\
\hline & $\begin{array}{l}\text { Hybrid dengue (consensus EDIII)-Ebola } \\
\text { recombinant immune complex (DERIC) } \\
\text { expressed in } N \text {. benthamiana }\end{array}$ & $\begin{array}{l}\text { Tetravalent candidate evaluated in } \\
\text { mice }\end{array}$ & [Kim et al., 2015] \\
\hline & $\begin{array}{l}\text { Tetravalent lipidated consensus EDIII } \\
\text { (LcED III) expressed in E. coli }\end{array}$ & $\begin{array}{l}\text { Tetravalent candidate evaluated in } \\
\text { mice }\end{array}$ & $\begin{array}{l}\text { [Chen et al., 2013; Chiang et al., 2011; } \\
\text { Leng et al., 2009] }\end{array}$ \\
\hline & $\begin{array}{l}\text { Lipidated EDIII (LED III) expressed } \\
\text { in E. coli }\end{array}$ & $\begin{array}{l}\text { Monovalent candidates (DV1,2,4) evalu- } \\
\text { ated in mice }\end{array}$ & [Chiang et al., 2011, 2013a,b] \\
\hline & $\begin{array}{l}\text { MixBiEDIII: bivalent EDIIIs (DV1-2/ } \\
\text { DV3-4) expressed in E. coli }\end{array}$ & $\begin{array}{l}\text { Tetravalent candidate evaluated in } \\
\text { mice }\end{array}$ & [Zhao et al., 2014] \\
\hline & $\begin{array}{l}\text { Bivalent EDIII (DV1-2) expressed in } \\
\text { E. coli }\end{array}$ & $\begin{array}{l}\text { Bivalent candidate (DV1-2) evaluated } \\
\text { in mice }\end{array}$ & [Zhang et al., 2015] \\
\hline & $\begin{array}{l}\text { Tetravalent chimeric EDIII expressed } \\
\text { in } P \text {. pastoris }\end{array}$ & $\begin{array}{l}\text { Tetravalent candidate evaluated in } \\
\text { mice }\end{array}$ & [Etemad et al., 2008] \\
\hline \multirow[t]{3}{*}{$\begin{array}{l}\text { Non-structural } \\
\text { proteins }\end{array}$} & $\begin{array}{l}\text { Recombinant DV2 NS1 protein ex- } \\
\text { pressed in E. coli }\end{array}$ & $\begin{array}{l}\text { Monovalent DV2 candidate evaluated } \\
\text { in mice }\end{array}$ & [Amorim et al., 2012] \\
\hline & $\begin{array}{l}\text { Recombinant DV2 NS1-DEC205 fusion } \\
\text { protein expressed in E. coli }\end{array}$ & $\begin{array}{l}\text { Monovalent DV2 candidate evaluated } \\
\text { in mice }\end{array}$ & [Henriques et al., 2013] \\
\hline & $\begin{array}{l}\text { Full-length recombinant DV2 NS3 pro- } \\
\text { tein expressed in E. coli }\end{array}$ & $\begin{array}{l}\text { Monovalent DV2 candidate evaluated } \\
\text { in mice }\end{array}$ & [Ramírez et al., 2014] \\
\hline Capsid protein & $\begin{array}{l}\text { Recombinant capsid protein expressed } \\
\text { in E. coli }\end{array}$ & $\begin{array}{l}\text { Monovalent DV2 candidate evaluated in } \\
\text { mice and NHPs }\end{array}$ & [Gil et al., 2009; 2014] \\
\hline
\end{tabular}

DV: dengue virus; E: envelope protein; EDII: envelope protein domain II; EDIII: envelope protein domain III; HBcAg: hepatitis B virus core antigen; prM: pre-membrane protein; NS1: non-structural protein 1; NS3: non-structural protein 3; VLP: virus-like particles; NHP: non-human primates

\subsection{Virus-like particles}

The proper folding of the E protein, needed to preserve the integrity of its neutralizing epitopes, generally requires co-expression with the prM protein (Allison et al., 1995). Co-expression of prM and $\mathrm{E}$ can induce the formation of virus-like particles (VLP), which are expected to be antigenically similar to dengue virions (Sugrue et al., 1997).
Based on the co-expression of the prM and E proteins, virus-like particles corresponding to all four DV serotypes have been produced in yeast (Pichia pastoris) and mammalian (293T) cells by the Sun Yat-Sen University, from China (Zhang et al., 2011; Liu et al., 2014). Immunization of mice with tetravalent or monovalent VLP formulations in Freund's adjuvant failed to induce potent neutralizing antibody responses. However, a tetravalent 
vaccine formulation had better protective efficacy than the monovalent VLP vaccine candidates in a suckling mouse model of encephalitis (Zhang et al., 2011). Differing cytokine secretion patterns were reported in these studies. DV2 VLP have been also expressed in insect Sf9 cells at the Kobe University, in Japan, but were found to be poorly immunogenic in mice when combined with a dinucleotide 5'-cytosine-guanine-3' (CpG) adjuvant (Kuwahara and Konishi, 2010). Neutralizing antibody titers increased when the DV2 VLP vaccine candidate was co-immunized with a plasmid DNA vaccine encoding the DV2 prM and E proteins.

The International Centre for Genetic Engineering and Biotechnology (ICGEB) from India has developed VLP of the DV2 E protein that were obtained for the first time in the absence of the prM protein (Mani et al., 2013). This approach reduces the risk of disease-enhancing activity attributed to anti-prM cross-reactive antibodies (Dejnirattisai et al., 2010). The recombinant E protein (N-terminal 395 aa residues) from DV2 was expressed at high levels in Pichia pastoris and assembled into VLP of 20-40 nm size. Inbred and outbred mice immunized with recombinant DV2 E VLP in alum produced high-titer neutralizing antibodies. The monovalent vaccine candidate provided partial protection against lethal DV2 challenge in AG129 mice. Further experiments are needed to determine the role, if any, of the DV2 E VLP-induced antibodies in antibody-dependent enhancement (ADE) of infection.

\subsection{Domain III-based fusion proteins}

Domain III of dengue virus E protein (EDIII) contains type-specific and subcomplex-specific epitopes that are dominant neutralization determinants (Roehrig, 2003). Antibodies specific for this viral domain are powerful blockers of DV infectivity (Crill and Roehrig, 2001). Importantly, E domain III has low potential for severe illness induction, since it elicits mainly serotype-specific antibodies (Simmons et al., 2001; Khanam et al., 2006).

\subsubsection{Domain III-P64k protein}

The Center for Genetic Engineering and Biotechnology (CIGB), in collaboration with the "Pedro Kouri" Tropical Medicine Institute (IPK) in Cuba, has developed recombinant proteins by fusing the E protein domain III (aa 286-426) of each DV serotype to the C-terminus of protein P64k from Neisseria meningitidis (Hermida et al., 2004a,b; Zulueta et al., 2006). The recombinant DV EDIII-P64k molecules were expressed in Escherichia coli in high yields. For the monovalent DV4 candidate, an additional viral fragment was inserted after the first 45 aa of P64k in order to enhance the immunogenicity of the protein (Lazo et al., 2009). A tetravalent vaccine formulation was evaluated in mice using alum as adjuvant (Lazo et al., 2014). After three intraperitoneal (i.p.) doses, neutralizing antibodies and interferon- $\gamma$ secretion were elicited against the four viral serotypes. Immunized animals were partially protected against intracranial challenge with lethal (DV1, DV2 or DV4) or encephalitis-inducing (DV3) virus one month after the last vaccine dose.

The monovalent formulations have also been evaluated in nonhuman primates using different immunization regimes. Crab-eating macaque (Macaca fascicularis) monkeys subcutaneously immunized with four doses $(50 \mu \mathrm{g}$ per dose) of the DV2 EDIII-P64k monovalent vaccine in Freund's adjuvant were protected from developing viremia when challenged with DV2 45 days after the last dose (Hermida et al., 2006). The DV1 EDIII-P64k vaccine candidate (100 $\mu$ g per dose) emulsified in Freund's adjuvant was highly immunogenic in $M$. fascicularis and rhesus monkeys after four subcutaneous (s.c.) doses and protected animals from viremia (Bernardo et al., 2008). However, when the vaccine candidate was formulated in alum it failed to induce a strong antibody response to protect animals from viral challenge. The immune responses induced by these recombinant proteins in mice and monkeys were found to be highly serotype-specific, with a low potential for inducing cross-reactive antibodies (Izquierdo et al., 2008). In an attempt to increase the immunogenicity of the EDIII-P64k fusion proteins, $100 \mu \mathrm{g}$ per dose of the DV2 vaccine candidate were administered either with outer membrane vesicles (OMV) or the serogroup A capsular polysaccharide (CPS) from Neisseria meningitidis, both adsorbed on alum (Valdés et al., 2009a). These formulations are suitable for use in humans. The antibody response after four doses to the formulation containing the CPS was clearly superior in Vervet monkeys to the one formulated with OMV. Moreover, only the group immunized with DV2 EDIII-P64k and CPS in alum was partially protected upon viral challenge.

\subsubsection{Domain III-dengue virus capsid protein}

A different approach, consisting of a recombinant $\mathrm{E}$ domain III-capsid (EDIIIC) fusion protein, was developed by the CIGB and the IPK with the goal of stimulating both humoral and cell-mediated immunity. The sequences coding for the envelope domain III fragments of the four DV serotypes (aa 286-426) were fused to the $\mathrm{N}$-terminus of the homologous capsid gene (Valdés et al., 2009b; Suzarte et al., 2014). Soluble recombinant EDIIIC proteins were expressed in E. coli. Incubation with a mixture of random-sequence oligodeoxynucleotides (ODN) yielded high-molecular-weight aggregates. Intraperitoneal immunization of mice with three doses (22.5 $\mu$ g each) of aggregated or non-aggregated forms of EDIIIC2 formulated in alum elicited similar levels of neutralizing antibodies. However, only the aggregated 
formulation protected the animals against lethal intracranial challenge with DV2 one month later (Valdés et al., 2009b). Both the humoral and cell-mediated immune responses induced by the recombinant protein in mice were highly serotype-specific, as determined by different immunological tests (Izquierdo et al., 2012).

The immunogenicity of EDIIIC2 was also evaluated in nonhuman primates after aggregation of the recombinant protein with the ODN 39M, which contains unmethylated CpG motifs. Monkeys immunized subcutaneously with 100 $\mu \mathrm{g}$ of EDIIIC2 (plus $10 \mu \mathrm{g}$ of ODN 39M) in alum developed a functional immune response that conferred partial protection from viremia when challenged thirty days after the fourth dose (Gil et al., 2015). A tetravalent vaccine candidate containing the DV2 EDIIIC combined with the EDIII-P64k fusion proteins from DV1, DV3 and DV4 was immunogenic and protected mice against challenge with lethal (DV1, DV2, DV4) or encephalitis-inducing (DV3) virus (Izquierdo et al., 2014). This formulation was also found to elicit a Th1-type response and high titers of neutralizing IgG1 and IgG2a antibodies specific for the four DV serotypes in mice (Zuest et al., 2015).

Different heterologous prime-boost strategies were evaluated in non-human primates by combining in the same schedule a live virus, simulating a LAV vaccine, and recombinant proteins containing the domain III of the DV2 envelope protein. In a first approach, monkeys were primed with a single dose of DV2 and boosted five months later with $300 \mu \mathrm{g}$ of EDIII-P64k (Valdés et al., 2010). In the second approach, monkeys received a single s.c. dose of DV2 and were boosted three months later with 100 $\mu \mathrm{g}$ of EDIIIC (Valdés et al., 2011). Administration of the recombinant proteins effectively boosted the neutralizing antibody responses elicited with the virus (Valdés et al., 2010; Valdés et al., 2011). These antibodies persisted at high levels (PRNT 50>300) for at least six months after the boost dose. In addition, high levels of IFN- $\gamma$ secretion were measured in the supernatants of cultured peripheral blood mononuclear cells extracted six months after the boost administration from the animals of both experiments. In a third prime-boost study, four doses of DV2 EDIII-P64k ( $100 \mu \mathrm{g}$ each) formulated in alum were followed by a single inoculation of DV2 45 days after the fourth dose (Valdés et al., 2010). The levels of neutralizing antibodies raised under the protein prime-DV2 boost regime were higher than those generated after one viral dose and similar to those elicited after two inoculations with the virus. Moreover, neutralizing antibodies were still detectable (PRNT 50 65) 14 months after the boost dose. Despite the limited number of animals in each experiment, the findings from these studies support the use of heterologous prime-boost strategies as an alternative to homologous prime-boost immunizations with replicating vaccines.

\subsubsection{Domain III-STF2}

VaxInnate has developed a self-adjuvanting vaccine platform based on the fusion of antigens to Salmonella enterica serovar Typhimurium FljB flagellin phase 2 (STF2), a Tolllike receptor 5 ligand. Other vaccine candidates produced with this platform were well tolerated and immunogenic in humans (Treanor et al., 2010; Taylor et al., 2011) and a flagellin-based West Nile Virus vaccine protected mice against experimental infection with this virus $(\mathrm{McD}$ onald $e t$ al., 2007). A tetravalent dengue vaccine candidate was created by replacing the D3 domain of STF2 with the E protein domain III from each DV serotype and fusing an additional copy of the domain III fragment to the C-terminus of STF2 (Liu et al., 2015). Proteins were produced in E. coli. The evaluation of immunogenicity in mice showed the induction of a potent neutralizing antibody response that lasted for up to seven months. Immunization of rhesus monkeys with three intramuscular injections of the tetravalent candidate ( $48 \mu \mathrm{g}$ total per dose) given at 1-month intervals elicited a shortlived neutralizing antibody response against the four DV serotypes. Monkeys were partially protected from viremia when challenged with DV2 one month after the last dose. No correlation was observed between the pre-challenge neutralization activity and protection. With the aim of incorporating additional potentially immunogenic epitopes, investigators now plan to develop flagellin-based vaccine candidates containing $80 \%$ of the DV envelope protein.

\subsubsection{Domain III-hepatitis B core antigen}

An alternative approach has been developed at the ICGEB by inserting the DV2 E protein domain III into the c/e1 loop of the hepatitis B virus core antigen ( $\mathrm{HBcAg}$ ) (Arora et al., 2013). The HBcAg is a well-documented carrier that can assemble into VLP and has been used in other vaccine candidates (Pumpens and Grens, 2001; Gregson et al., 2008; Fiers et al., 2009). VLP formation was confirmed after high-yield expression $(26 \mathrm{mg} / \mathrm{l})$ of the recombinant protein in Pichia pastoris. Immunization of mice with three doses of the protein formulated in alum elicited a modest neutralizing antibody response (PRNT 50 40) (Arora et al., 2013). A previous attempt using antigen produced in the $E$. coli expression system had resulted in similar neutralizing antibody titers (Arora et al., 2012).

\subsubsection{Domain II-domain III-NS1 fusion protein}

Two parallel strategies are currently under development at the CINVESTAV-IPN, in Mexico. In one approach, DV2 recombinant fusion proteins that contain a fragment of the E protein domain II (aa 35-121) and the whole domain III, with or without the C-terminally truncated (aa 57-130) NS1 protein were developed (García-Machorro et al., 2013). Two additional chimeric candidates were generated by fusion with three copies of the P28 region of the complement 
protein C3d, known to have adjuvant activity. The four recombinant proteins were expressed using Drosophila S2 cells. A predominant IgG1 antibody response was detected in mice after immunization at 15-day intervals with any of the four recombinant proteins $(25 \mu \mathrm{g}$ per dose $)$ emulsified in incomplete Freund's adjuvant. Although not all animals seroconverted, high titers of neutralizing antibodies were elicited in the four vaccine groups. A prime-boost strategy was also assayed in mice by priming with three i.m. doses $(100 \mu \mathrm{g} / 100$ $\mu \mathrm{l}$ per dose) of a plasmid encoding for the domains II and III of the envelope protein and the $75 \mathrm{~N}$-terminal amino acids of the NS1 protein from DV2, followed by a boost with a single intradermal dose of recombinant E and NS1 proteins (35 $\mu \mathrm{g}$ each) emulsified in Freund's adjuvant (Mellado-Sánchez et al., 2010). Only $40 \%$ of the immunized mice produced neutralizing antibodies against DV2.

\subsubsection{Domain III-DEC-205}

The other approach developed at the CINVESTAV-IPN is based on targeting dendritic cells with the E protein domain III of DV2 (Coconi-Linares et al., 2013). DEC-205 is a 205 $\mathrm{K}$ molecule that is expressed primarily by dendritic cells and mediates antigen uptake for presentation on MHC class II and cross-presentation on MHC class I (Bozzacco et al., 2007; Birkholz et al., 2010). A recombinant protein formed by the EDIII (aa 268-394) fused to a single chain antibody fragment $(\mathrm{scFv})$ specific for DEC-205 was tested in mice. Two s.c. doses ( $25 \mu \mathrm{g}$ per dose given at two-week intervals) of scFvDEC205-EDIII induced neutralizing antibodies that did not increase with the use of $25 \mu \mathrm{g}$ aCD40 plus $25 \mu \mathrm{g}$ polyriboinosinic: polyribocytidylic acid (poly (I:C)) adjuvant (Coconi-Linares et al., 2013). Further optimization of expression in the Nicotiana benthamiana system is needed to overcome the low protein yield $(0.05 \%-0.08 \%$ of total soluble protein) in this approach.

\subsubsection{DERIC}

The Arizona State University (USA) and the National Research Foundation of Korea have collaborated in a novel dengue vaccine based on recombinant immune complexes (RIC). RIC are generated by fusing an antigen to a monoclonal antibody specific for that antigen. The antibody portion can recognize the antigen on a similar molecule and bind to form immune complex-like structures. In this approach, the authors incorporated a dengue E protein consensus domain III into a modified Ebola RIC molecular platform to create a hybrid dengue-Ebola RIC (DERIC) (Kim et al., 2015). Human and mouse versions of DERIC were expressed in $N$. benthamiana plants. The immunogenicity of the mouse variant containing the heavy and light chains of the antibody was evaluated in mice after three doses of the antigen $(6.8 \mu \mathrm{g} / 100 \mu \mathrm{l}$ per dose at three-week intervals) in the absence of adjuvant. All immunized animals produced neutralizing antibodies against DV4 (mean titer of 1:40), but only $30 \%$ of them had functional seroconversion against DV2.

\subsubsection{Lipidated domain III}

A novel dengue subunit vaccine was designed by the $\mathrm{Na}$ tional Health Research Institutes and the China Medical University, from Taiwan, that contains the consensus E protein domain III derived from the four serotypes of DV. Lipidated (LcED III) and non-lipidated (cED III) forms of the vaccine were produced in E. coli and evaluated in vivo (Chiang et al., 2011). The lipid moiety of the recombinant lipoprotein contains a ligand for toll-like receptor 2 (Leng et al., 2010), that provides the proteins with self-adjuvanting properties. The cED III formulated with aluminum phosphate $(20 \mu \mathrm{g}$ per dose given three times at two-week intervals) induced neutralizing antibodies against the four DV serotypes in mice (Leng et al., 2009), but only DV2-specific neutralizing antibodies in two of three immunized monkeys (Chen et al., 2013). The lipidated consensus dengue virus $\mathrm{E}$ protein domain III activated macrophages and up-regulated the expression of CD40, MHC II, and co-stimulatory molecules in vitro (Chiang et al., 2011). In addition, it was superior to cED III in inducing DV domain III-specific T-cell proliferative responses, IFN- $\gamma$ secretion, and IgG production. Despite the low cross-neutralizing antibody titers induced by LcED III, a significant anamnestic neutralizing antibody response was detected in immunized mice (1-20 $\mu$ g; single s.c. dose) after challenge with DV.

In a different approach, the individual E protein domain III from DV serotypes 1, 2 and 4 were expressed in lipidated form (LD1ED III, LD2ED III, LD4ED III) in E. coli. Mice were immunized in separate experiments with two doses of the lipidated proteins $(10 \mu \mathrm{g} / 0.2 \mathrm{ml}$ per dose $)$ in the $\mathrm{ab}$ sence of exogenous adjuvants. Immunization with LD4ED III resulted in higher frequencies of B cells secreting antiDV4 E protein domain III-specific antibodies than with the non-lipidated form. Despite the poor neutralizing antibody response (titers ranging from 1:8 to 1:16), mice had reduced viremia after challenge with DV4-infected K562 cells (Chiang et al., 2014). LD2ED III stimulated significant neutralizing antibody responses (FRNT $50=84)$ that were further increased (FRNT 50 of 588 and 1176 at 4 and 20 weeks after priming, respectively) after booster immunization with DV2 (Chiang et al., 2013a). In addition, sera from LD2ED III-immunized animals had reduced ADE activity when compared to those from animals immunized with DV2. The LD1ED III vaccine candidate induced up-regulation of activation markers and IL-6 production on RAW 264.7 macrophage cells (Chiang et al., 2013b). Immunization of mice with LD1ED III elicited a long-lasting neutralizing antibody response that was increased when the protein was combined with a water-in-oil-in-water nanoemulsion containing a bioresorbable polymer, $\operatorname{Span}^{\circledR} 85$, and squalene. 
LD1ED III combined with this multiphase emulsion system also elicited the highest T cell proliferation and IFN- $\gamma$ secretion rates.

\subsubsection{Bivalent or tetravalent domain III}

A novel approach for a tetravalent EDIII vaccine, developed by the Beijing Institute of Microbiology and Epidemiology and the Wuhan University, in China, is based on the mixture of two bivalent EDIIIs of DV (type 1-2 and type 3-4), each connected by a Gly-Ser linker and expressed in E. coli (Zhao et al., 2014). Sera from mice immunized with three doses of MixBiEDIII ( $50 \mu \mathrm{g}$ of each bivalent protein per dose) given at two-week intervals in Freund's adjuvant had neutralizing antibodies and provided significant protection against the four serotypes of DV in a suckling mouse model. A previous attempt by this group using a protein tandem in which the EDIII of all four DV serotypes were sequentially connected, resulted in very poor immunogenicity and failed to protect mice against lethal DV3 infection (Chen et al., 2007).

The Fujian Medical University and the Fujian Center for Disease Control and Prevention have also produced a chimeric bivalent protein expressed in $E$. coli that contains the envelope domain IIIs of dengue serotypes 1 and 2 (DV-1/2) connected by a Gly-Ser linker (Zhang et al., 2015). Mice were immunized with the bivalent protein, a DNA vaccine coding for that protein, or the combination of both. The recombinant protein-DNA vaccine combination elicited significantly higher titers of DV1 - or DV2-specific neutralizing antibody than the other two formulations.

A tetravalent chimeric protein created at the ICGEB by fusing the E domain III (EDIII, aa 296-415) of the four DV serotypes and expressed in $P$. pastoris induced neutralizing antibodies against all four serotypes in mice (Etemad et al., 2008). The monovalent DV2 envelope protein domain III (EDIII-2, aa 297-400) was also found to elicit high levels of DV2-specific neutralizing antibodies in mice when formulated in either alum or montanide ISA 720 (Batra et al., 2010).

\section{Non-structural protein-based vaccines}

\subsection{NS1}

The University of São Paulo, from Brazil, has worked on the development of different NS1-based vaccine candidates. In a first approach, they evaluated the safety and immunogenicity in mice of a recombinant DV2 NS1 protein expressed in E. coli and formulated with three different adjuvants: alum, Freund's adjuvant or a non-toxic variant of E. coli heat-labile enterotoxin LTG33D (Amorim et al., 2012). Mice receiving four doses of the NS1-LTG33D com- bination $(10 \mu \mathrm{g}$ NS1 plus $1 \mu \mathrm{g}$ LTG33D) by the s.c. route elicited the strongest antibody response, with a balanced IgG1/IgG2a ratio and enhanced avidity to the NS1 protein. The anti-NS1 cytotoxic activity was low in all vaccinated groups. The NS1-LTG33D formulation also produced the highest protection level (50\%) against challenge with DV2 among all the experimental groups. No significant hepatic damage or hematological disturbances were induced by the administration of NS1 combined with LTG33D.

The second approach targets the NS1 protein from DV to dendritic cells. The DV2 NS1 protein was fused to the Cterminus of monoclonal antibodies specific for the endocytic receptors DEC-205 or DCIR2, expressed on the surface of two distinct dendritic cell populations (Henriques et al., 2013). $\mathrm{BALB} / \mathrm{c}$ mice were intraperitoneally immunized with two 5 $\mu \mathrm{g}$ doses of each fusion protein in the presence of poly (I:C) as a dendritic cell maturation stimulus. Potent anti-NS1 antibody responses were detected in the groups immunized with the dendritic cell-targeting vaccine candidates, although the anti-DEC205-NS1 fusion protein induced higher numbers of IFN- $\gamma$-producing cells. This protein also conferred the highest level of protection from lethal challenge with DV2, which was partially mediated by CD $4+$ and CD $8+T$ cells. Incorporation of the E protein or immunogenic fragments thereof is planned for both approaches. Further considerations should be taken into account regarding the safety of NS1 as a vaccine antigen. The C-terminal amino acid residues 311-352 of DV NS1 share sequence homology with host cell target proteins in endothelial cells and platelets (Lin et al., 2011), and the deletion of this region has been found to abolish anti-NS1-antibody mediated platelet dysfunction and bleeding tendency (Wan et al., 2008; Chen et al., 2009). Therefore, the NS1 epitopes that induce cross-reactive antibodies will likely need to be removed or modified in future NS1 vaccine approaches.

\subsection{NS3}

Recently, the immunogenicity of a recombinant DV2 fulllength NS3 protein was evaluated by the group from the IPK. The protein was expressed in E. coli as inclusion bodies that were purified and refolded. The purified NS3 protein was recognized by mouse anti-DV polyclonal sera and induced IFN- $\gamma$ secretion after in vitro stimulation of splenocytes from DV2-infected mice (Ramírez et al., 2014). Mice intraperitoneally injected with three doses of NS3 emulsified with Freund's adjuvant ( $20 \mu \mathrm{g}$ per dose) elicited anti-NS3 antibodies with titers ranging from 1:16,000 to 1:64,000, and IgG2b as the predominant subclass. The protective efficacy of the recombinant NS3 protein was not reported. In an alternative attempt, the NS3 from the four DV serotypes was expressed in E. coli at the University of Veracruz, Mexico, but the proteins were poorly immunogenic in mice (AlvarezRodríguez et al., 2012). 


\section{Capsid protein-based vaccine}

The induction of neutralizing antibodies has historically been considered the primary goal in dengue vaccine design (Halstead, 2012). However, the potential risk of ADE resulting from an unbalanced humoral immune response or waning antibody levels after vaccination has led to suggestions that a safer and more efficient DV vaccine should trigger both humoral and cellular immune responses (Zellweger et al., 2013). Increasing evidence suggests that CD4+ and CD8+ T-cells may play protective roles during dengue infection (Weiskopf and Sette, 2014). It has been reported that both CD4+ and CD8+ T cells contribute to protection against DV challenge in murine models of infection (Yauch et al., 2009; Yauch et al., 2010). DV-specific human CD4+ T and CD8+ T cells have been shown to proliferate, secrete IFN- $\gamma$, and lyse infected target cells (Kurane et al., 1989; Mathew et al., 1996; Gagnon et al., 1999), suggesting that serotype-specific T cells are functionally activated during primary DV infections in humans (Kurane et al., 1989). Moreover, higher frequencies of DV-specific IFN- $\gamma$-producing T cells were detected in children who subsequently developed subclinical infection, compared with those who developed symptomatic secondary DV infection (Hatch et al., 2011).

In view of these findings, a vaccine candidate relying exclusively on the induction of cell-mediated immunity could be an attractive alternative approach for a safer dengue vaccine. The CIGB, in collaboration with the IPK, has developed a vaccine candidate based on the capsid $(C)$ protein from dengue virus. The $\mathrm{C}$ protein is known to be a target of the antiviral T-cell response (Gagnon et al., 1996; Gagnon et al., 1999) and experiments in mice have demonstrated the protective role of two of its epitopes (Yauch et al., 2009). Several bioinformatic analyses have predicted the serotype specificity of the C protein (Khromykh and Westaway, 1996; Khan et al., 2006), for which no altered peptide ligands have been described. The recombinant C protein (aa 1-99) from DV2 virus Jamaica 1409 strain was expressed in E. coli (Lazo et al., 2007). The carboxy-terminal hydrophobic signal sequence was excluded from the initial construct to minimize potential solubility problems associated with the full-length $\mathrm{C}$ protein. An in vitro particulation process for the purified protein was established and led to the formation of viruslike particles of 25-30 nm in diameter (López et al., 2008), close to the size of native capsid particles (Kuhn et al., 2002). This particulation process was independent of the length or sequence of the oligodeoxynucleotides used to neutralize the positive charges on the capsid dimers. The sera from mice immunized by the i.p. route with three doses of $\mathrm{C}$ protein VLP $(10-20 \mu \mathrm{g} / 100 \mu \mathrm{l}$ per dose given at 15-day intervals) adjuvanted with alum failed to neutralize DV2 infectivity in vitro. However, splenocytes from the immunized animals secreted high levels of IFN- $\gamma$ upon virus stimulation. A sig- nificant protection rate (78\%) was achieved after challenge with lethal DV2 (Gil et al., 2009). Both IFN- $\gamma$ secretion and protection were dependent on CD4+ and CD8+ cells.

Nonhuman primates subcutaneously immunized with $50 \mu \mathrm{g} / 0.5 \mathrm{ml}$ of the recombinant VLP based on the C protein from DV2 did not produce neutralizing antibodies after four doses given at two-month intervals (Gil et al., 2014). However, IFN- $\gamma$ secretion and cellular cytotoxicity were detected when peripheral blood mononuclear cells from these animals were stimulated in vitro with DV2. Although only one of the three immunized monkeys was fully protected against challenge with DV2, a significant reduction of the viral load was observed in the vaccine group. Strategies are planned to enrich the recombinant $\mathrm{C}$ protein with $\mathrm{T}$-cell epitopes and/or evaluate novel potent adjuvants that may enhance the cell-mediated immune response to the $\mathrm{C}$ protein VLP. Future studies will also assess shortened immunization schedules and long-term immune status.

Finally, the immunopotentiating capacity of the DV2 capsid protein VLP has been assessed in co-immunization experiments in mice using two chimeric fusion proteins in which the E protein domain III from DV1 or DV4 is fused to the carrier protein P64k. The DV1 EDIII-P64k fusion protein had previously proved to be immunogenic and protective in nonhuman primates when Freund's adjuvant, but not alum, was used (Bernardo et al., 2008). In turn, the DV4 EDIII-P64k protein was poorly immunogenic in mice (Lazo et al., 2009). Immunization with three i.p. doses (at 15-day intervals) of DV1 EDIII-P64k $(10 \mu \mathrm{g})$ and DV2 C protein VLP $(10 \mu \mathrm{g})$ combined in alum induced a DV1specific neutralizing antibody response, with higher titers than in the group immunized with DV1 (Lazo et al., 2012). High levels of IFN- $\gamma$ secretion were detected after in vitro stimulation with DV1 and DV2 of the splenocytes extracted from immunized animals. The DV1 EDIII-P64k-VLP formulation provided significant protection against challenge with DV1 or DV2 one month after the last dose. Similarly, higher anti-viral antibody titers and protection rates (90\% versus 60\%) against DV4 were induced with DV4 EDIII-P64k in the presence of VLP, as compared with DV4 EDIII-P64k alone (Lazo et al., 2010).

\section{Conclusions}

Dengue continues to be a major burden in tropical and subtropical regions of the world, but many unique challenges have hindered the development of an effective vaccine against the virus. The most advanced vaccine in clinical development is the recombinant tetravalent dengue vaccine (CYD-TDV) developed by the Sanofi Pasteur Group. The two phase III trials recently completed showed a moderate efficacy of $56.5 \%$ in Asia and $60.8 \%$ in Latin America (Capeding et 
al., 2014; Villar et al., 2015), with significant reductions in severe disease and hospitalization rates. These results are encouraging, but should be cautiously interpreted in light of the short observation period. Safety concerns still remain and a number of limitations need to be addressed. Recombinant protein-based vaccines may provide safer alternatives to LAV vaccines if the poorer immunogenicity of existing candidates can be overcome with novel antigen design and immunopotentiating strategies. Subunit dengue vaccines could be administered in shorter schedules requiring fewer doses, and be more suitable for specific population groups, such as immunocompromised persons, travelers, infants, or elderly individuals. The combination of subunit vaccines and LAV vaccines in heterologous prime-boost approaches could help reduce the number of administrations of the LAV vaccine component and the length of immunization schedules, providing a safer, more convenient and economic option for scale up in national programs. Finally, increasing evidence on the role of the cell-mediated immunity in protection against DV infection supports the evaluation of subunit vaccines relying exclusively on antibody-independent mechanisms.

\section{References}

Allison SL, Stadler K, Mandl CW, Kunz C, Heinz, FX, J. Virol. 69, 5816-5820, 1995.

Alvarez-Rodríguez LM, Ramos-Ligonio A, Rosales-Encina JL, Martínez-Cázares MT, Parissi-Crivelli A, López-Monteon A, J. Trop. Med. 2012, 956875, 2012. http://dx.doi. org/10.1155/2012/956875

Amorim JH, Diniz MO, Cariri FA, Rodrigues JF, Bizerra RS, Gonçalves AJ, de Barcelos Alves AM, de Souza Ferreira LC,Vaccine 30, 837-845, 2012. http://dx.doi.org/10.1016/j. vaccine.2011.12.034

Arora U, Tyagi P, Swaminathan S, Khanna N, J. Nanobiotechnology 10, 1-6, 2012. http://dx.doi.org/10.1186/1477-3155-10-30

Arora U, Tyagi P, Swaminathan S, Khanna N, Vaccine 31, 873-878, 2013. http://dx.doi.org/10.1016/j.vaccine.2012.12.016

Batra G, Raut R, Dahiya S, Kamran N, Swaminathan S, Khanna N, J. Virol. Methods 167, 10-16, 2010. http://dx.doi. org/10.1016/j.jviromet.2010.03.002

Bernardo L, Izquierdo A, Alvarez M, Rosario D, Prado I, López C, Martínez R, Castro J, Santana E, Hermida L, Guillen G, Guzmán MG, Antiviral Res. 80, 194-199, 2008. http:// dx.doi.org/10.1016/j.antiviral.2008.06.005

Bhatt S, Gething PW, Brady OJ, Messina JP, Farlow AW, Moyes CL, Drake JM, Brownstein JS, Hoen AG, Sankoh O, Myers MF, George DB, Jaenisch T, Wint GR, Simmons CP, Scott TW, Farrar JJ, Hay SI, Nature 496, 504-507, 2013. http:// dx.doi.org/10.1038/nature12060

Birkholz K, Schwenkert M, Kellner C, Gross S, Fey G, SchulerThurner B, Schuler G, Schaft N, Dörrie J, Blood 116, 2277-2285, 2010. http://dx.doi.org/10.1182/blood-2010 $\underline{-02-268425}$
Bozzacco L, Trumpfheller C, Siegal FP, Mehandru S, Markowitz M, Carrington M, Nussenzweig MC, Piperno AG, Steinman RM, Proc. Natl. Acad. Sci. U S A 104, 1289-1294, 2007. http://dx.doi.org/10.1073/pnas.0610383104

Capeding MR, Tran NH, Hadinegoro SR, Ismail HI, Chotpitayasunondh T, Chua MN, Luong CQ, Rusmil K, Wirawan DN, Nallusamy R, Pitisuttithum P, Thisyakorn U, Yoon IK, van der Vliet D, Langevin E, Laot T, Hutagalung Y, Frago C, Boaz M, Wartel TA, Tornieporth NG, Saville M, Bouckenooghe A; CYD14 Study Group, Lancet 384, 1358-1365, 2014. http://dx.doi.org/10.1016/S0140-6736(14)61060-6

Chambers TJ, Hahn CS, Galler R, Rice CM, Annu. Rev. Microbiol. 44, 649-688, 1990. http://dx.doi.org/10.1146/annurev. mi.44.100190.003245

Chen HW, Liu SJ, Li YS, Liu HH, Tsai JP, Chiang CY, Chen MY, Hwang CS, Huang CC, Hu HM, Chung HH, Wu SH, Chong P, Leng CH, Pan CH, Arch. Virol. 158, 1523-1531, 2013. http://dx.doi.org/10.1007/s00705-013-1639-1

Chen MC, Lin CF, Lei HY, Lin SC, Liu HS, Yeh TM, Anderson R, Lin YS, J. Immunol. 183, 1797-1803, 2009. http://dx.doi. org/10.4049/jimmunol.0800672

Chen S, Yu M, Jiang T, Deng Y, Qin C, Qin E, DNA Cell. Biol. 26, 361-367, 2007. http://dx.doi.org/10.1089/dna.2006.0547

Chiang CY, Liu SJ, Tsai JP, Li YS, Chen MY, Liu HH, Chong P, Leng CH, Chen HW, PLoS One 6, e23319, 2011. http://dx.doi. org/10.1371/journal.pone.0023319

Chiang CY, Pan CH, Hsieh CH, Tsai JP, Chen MY, Liu HH, Liu SJ, Chong P, Leng CH, Chen HW, PLoS Negl. Trop. Dis. 7, e2432, 2013a. http://dx.doi.org/10.1371/journal. pntd.0002432

Chiang CY, Huang MH, Pan CH, Hsieh CH, Chen MY, Liu HH, Tsai JP, Liu SJ, Chong P, Leng CH, Chen HW, Microbes Infect. 15, 719-728, 2013b. http://dx.doi.org/10.1016/j. micinf.2013.06.002

Chiang CY, Hsieh CH, Chen MY, Tsai JP, Liu HH, Liu SJ, Chong P, Leng CH, Chen HW, Vaccine 32, 1346-1353, 2014. http:// dx.doi.org/10.1016/j.vaccine.2014.01.041

Clements DE, Coller BA, Lieberman MM, Ogata S, Wang G, Harada KE, Putnak JR, Ivy JM, McDonell M, Bignami GS, Peters ID, Leung J, Weeks-Levy C, Nakano ET, Humphreys T, Vaccine 28, 2705-2715, 2010. http://dx.doi.org/10.1016/j. vaccine.2010.01.022

Coconi-Linares N, Ortega-Dávila E, López-González M, GarcíaMachorro J, García-Cordero J, Steinman RM, CedilloBarrón L, Gómez-Lim MA, Vaccine 31, 2366-2371, 2013. http://dx.doi.org/10.1016/j.vaccine.2013.03.009

Coller BA, Clements DE, Bett AJ, Sagar SL, Ter Meulen JH, Vaccine 29, 7267-7275, 2011. http://dx.doi.org/10.1016/j. vaccine.2011.07.021

Crill WD, Roehrig JT, J. Virol. 75, 7769-7773, 2001. http://dx.doi. org/10.1128/JVI.75.16.7769-7773.2001

Dejnirattisai W, Jumnainsong A, Onsirisakul N, Fitton P, Vasanawathana S, Limpitikul W, Puttikhunt C, Edwards C, Duangchinda T, Supasa S, Chawansuntati K, Malasit P, Mongkolsapaya J, Screaton G, Science 328, 745-748, 2010. http://dx.doi.org/10.1126/science.1185181 
Etemad B, Batra G, Raut R, Dahiya S, Khanam S, Swaminathan S, Khanna N, Am. J. Trop. Med. Hyg. 79, 353-363, 2008.

Fiers W, De Filette M, El Bakkouri K, Schepens B, Roose K, Schotsaert M, Birkett A, Saelens X, Vaccine 27, 6280-6283, 2009. http://dx.doi.org/10.1016/j.vaccine.2009.07.007

Gagnon SJ, Zeng W, Kurane I, Ennis FA, J. Virol. 70, 141-147, 1996.

Gagnon SJ, Ennis FA, Rothman AL, J. Virol. 73, 3623-3629, 1999.

García-Machorro J, López-González M, Barrios-Rojas O, Fernández-Pomares C, Sandoval-Montes C, Santos-Argumedo L, Villegas-Sepúlveda N, Gutiérrez-Casta-eda B, CedilloBarrón L, Hum. Vaccin. Immunother. 9, 2326-2335, 2013. http://dx.doi.org/10.4161/hv.25673

Gil L, López C, Lazo L, Valdés I, Marcos E, Alonso R, Gambe A, Martín J, Romero Y, Guzmán MG, Guillén G, Hermida L, Int. Immunol. 21, 1175-1183, 2009. http://dx.doi. org/10.1093/intimm/dxp082

Gil L, Izquierdo A, Lazo L, Valdés I, Ambala P, Ochola L, Marcos E, Suzarte E, Kariuki T, Guzmán G, Guillén G, Hermida L, Virology 456-457, 70-76, 2014. http://dx.doi. org/10.1016/j.virol.2014.03.011

Gil L, Marcos E1, Izquierdo A, Lazo L, Valdés I, Ambala P, Ochola L, Hitler R, Suzarte E, Álvarez M2, Kimiti P, Ndung'u J, Kariuki T, Guzmán MG, Guillén G, Hermida L, Immunol. Cell. Biol. 93, 57-66, 2015. http://dx.doi.org/10.1038/ icb. 2014.63

Gregson AL, Oliveira G, Othoro C, Calvo-Calle JM, Thorton GB, Nardin E, Edelman R, PLoS One 3, e1556, 2008.

Gubler DJ, Vaccine Companion 4, 1-3, 2011.

Guy B, Barban V, Mantel N, Aguirre M, Gulia S, Pontvianne J, Jourdier TM, Ramirez L, Gregoire V, Charnay C, Burdin N, Dumas R, Lang J, Am. J. Trop. Med. Hyg. 80, 302311, 2009.

Halstead SB, Lancet 380, 1535-1536, 2012. http://dx.doi. org/10.1016/S0140-6736(12)61510-4

Hansson M, Nygren PA, Ståhl S, Biotechnol. Appl. Biochem. 32, 95-107, 2000. http://dx.doi.org/10.1042/BA20000034

Hatch S, Endy TP, Thomas S, Mathew A, Potts J, Pazoles P, Libraty DH, Gibbons R, Rothman AL, J. Infect. Dis. 203, 12821291, 2011. http://dx.doi.org/10.1093/infdis/jir012

Henriques HR, Rampazo EV, Gonçalves AJ, Vicentin EC, Amorim JH, Panatieri RH, Amorim KN, Yamamoto MM, Ferreira LC, Alves AM, Boscardin SB, PLoS Negl. Trop. Dis. 7, e2330, 2013. http://dx.doi.org/10.1371/journal.pntd.0002330

Hermida L, Rodríguez R, Lazo L, Bernardo L, Silva R, Zulueta A, López C, Martín J, Valdés I, del Rosario D, Guillén G, Guzmán MG, Biotechnol. Appl. Biochem. 39, 107-114, 2004a. http://dx.doi.org/10.1042/BA20030039

Hermida L, Rodríguez R, Lazo L, Silva R, Zulueta A, Chinea G, López C, Guzmán MG, Guillén G, J. Virol. Methods 115, 41-49, 2004b. http://dx.doi.org/10.1016/j. jviromet.2003.09.024

Hermida L, Bernardo L, Martín J, Alvarez M, Prado I, López C, Sierra Bde L, Martínez R, Rodríguez R, Zulueta A, Pérez AB, Lazo L, Rosario D, Guillén G, Guzmán MG, Vaccine 24, 3165-3171, 2006. http://dx.doi.org/10.1016/j. vaccine.2006.01.036
Izquierdo A, Bernardo L, Martin J, Santana E, Hermida L, Guillén G, Guzmán MG, Virus Res. 138, 135-138, 2008. http:// dx.doi.org/10.1016/j.virusres.2008.08.008

Izquierdo A, Valdés I, Gil L, Hermida L, Gutiérrez S, García A, Bernardo L, Pavón A, Guillén G, Guzmán MG, Antiviral Res. 95, 1-8, 2012. http://dx.doi.org/10.1016/j. antiviral.2012.04.006

Izquierdo A, García A, Lazo L, Gil L, Marcos E, Alvarez M, Valdés I, Hermida L, Guillén G, Guzmán MG, Arch. Virol. 159, 2597-2604, 2014. http://dx.doi.org/10.1007/s00705-014 $\underline{-2115-2}$

Khan AM, Heiny AT, Lee KX, Srinivasan KN, Tan TW, August JT, Brusic V, BMC Bioinformatics 7 (Suppl. 5), S4, 2006. http://dx.doi.org/10.1186/1471-2105-7-S5-S4

Khanam S, Etemad B, Khanna N, Swaminathan S, Am. J. Trop. Med. Hyg. 74, 266-277, 2006.

Khromykh AA, Westaway EG, Arch. Virol. 141, 685-699, 1996. http://dx.doi.org/10.1007/BF01718326

Kim MY, Reljic R, Kilbourne J, Ceballos-Olvera I, Yang MS, Reyesdel Valle J, Mason HS, Vaccine 33, 1830-1838, 2015. http:// dx.doi.org/10.1016/j.vaccine.2015.02.036

Kitchener S, Nissen M, Nasveld P, Forrat R, Yoksan S, Lang J, Saluzzo JF, Vaccine 24, 1238-1241, 2006. http://dx.doi. org/10.1016/j.vaccine.2005.09.029

Kuhn RJ, Zhang W, Rossmann MG, Pletnev SV, Corver J, Lenches E, Jones CT, Mukhopadhyay S, Chipman PR, Strauss EG, Baker TS, Strauss JH, Cell 108, 717-725, 2002. http:// dx.doi.org/10.1016/S0092-8674(02)00660-8

Kurane I, Meager A, Ennis FA, J. Exp. Med. 170, 763-775, 1989. http://dx.doi.org/10.1084/jem.170.3.763

Kuwahara M, Konishi E, Clin. Vaccine Immunol. 17, 1560-1566, 2010. http://dx.doi.org/10.1128/CVI.00087-10

Lazo L, Hermida L, Zulueta A, Sánchez J, López C, Silva R, Guillén G, Guzmán MG, Vaccine 25, 1064-1070, 2007. http:// dx.doi.org/10.1016/j.vaccine.2006.09.068

Lazo L, Zulueta A, Hermida L, Blanco A, Sánchez J, Valdés I, Gil L, López C, Romero Y, Guzmán MG, Guillén G, Biotechnol. Appl. Biochem. 52, 265-271, 2009. http://dx.doi. org/10.1042/BA20080074

Lazo L, Gil L, Lopez C, Valdes I, Marcos E, Alvarez M, Blanco A, Romero Y, Falcon V, Guzmán MG, Guillén G, Hermida L, Arch. Virol. 155, 1587-1595, 2010. http://dx.doi. org/10.1007/s00705-010-0734-9

Lazo L, Gil L, López C, Valdés I, Blanco A, Pavón A, Romero Y, Guzmán MG, Guillén G, Hermida L, Acta Trop. 124, 107-112, 2012. http://dx.doi.org/10.1016/j. actatropica.2012.06.006

Lazo L, Izquierdo A, Suzarte E, Gil L, Valdés I, Marcos E, Álvarez M, Romero Y, Guzmán MG, Guillén G, Hermida Cruz L, Microbiol. Immunol. 58, 219-226, 2014. http://dx.doi. org/10.1111/1348-0421.12140

Leng CH, Liu SJ, Tsai JP, Li YS, Chen MY, Liu HH, Lien SP, Yueh A, Hsiao KN, Lai LW, Liu FC, Chong P, Chen HW, Microbes Infect. 11, 288-295, 2009. http://dx.doi.org/10.1016/j. micinf.2008.12.004

Leng CH, Chen HW, Chang LS, Liu HH, Liu HY, Sher YP, Chang YW, Lien SP, Huang TY, Chen MY, Chou AH, Chong P, 
Liu SJ, Mol. Immunol. 47, 2015-2021, 2010. http://dx.doi. org/10.1016/j.molimm.2010.04.012

Lin YS, Yeh TM, Lin CF, Wan SW, Chuang YC, Hsu TK, Liu HS, Liu CC, Anderson R, Lei HY, Exp. Biol. Med. (Maywood) 236, 515-523, 2011. http://dx.doi.org/10.1258/ ebm.2011.010339

Liu G, Song L, Beasley DW, Putnak R, Parent J, Misczak J, Li H, Reiserova L, Liu X, Tian H, Liu W, Labonte D, Duan L, Kim Y, Travalent L, Wigington D, Weaver B, Tussey L, Clin. Vaccine Immunol. 22, 516-525, 2015. http://dx.doi. org/10.1128/CVI.00770-14

Liu Y, Zhou J, Yu Z, Fang D, Fu C, Zhu X, He Z, Yan H, Jiang L, BMC Microbiol. 14, 233, 2014. http://dx.doi.org/10.1186/ s12866-014-0233-3

López C, Lazo L, Gil L, Hermida L, Guillén G, Guzmán MG, Vázquez S, Bernardo L, Zulueta A, Martín J, Valdés I, Sánchez J, Blanco A, Romero Y, Menéndez I, de la Rosa MC, Márquez G, Silva R, Falcón V, Selman-Housein M, Biotecnología Aplicada 25, 52-53, 2008.

Mani S, Tripathi L, Raut R, Tyagi P, Arora U, Barman T, Sood R, Galav A, Wahala W, de Silva A, Swaminathan S, Khanna N, PLoS One 8, e64595, 2013. http://dx.doi.org/10.1371/ journal.pone.0064595

Manoff SB, George SL, Bet AJ, Yelmene ML, Dhanasekaran G, Eggemeyer L, Sausser ML, Dubey SA, Casimiro DR, Clements DE, Martyak T, Pai V, Parks DE, Coller BA, Vaccine 33, 7126-7134, 2015. http://dx.doi.org/10.1016/j. vaccine.2015.09.101

Mathew A, Kurane I, Rothman AL, Zeng LL, Brinton MA, Ennis FA, J. Clin. Invest. 98, 1684-1691, 1996. http://dx.doi. org/10.1172/JCI118964

McDonald WF, Huleatt JW, Foellmer HG, Hewitt D, Tang J, Desai P, Price A, Jacobs A, Takahashi VN, Huang Y, Nakaar V, Alexopoulou L, Fikrig E, Powell TJ, J. Infect. Dis. 195, 1607-1617, 2007. http://dx.doi.org/10.1086/517613

Mellado-Sánchez G, García-Machorro J, Sandoval-Montes C, Gutiérrez-Casta-eda B, Rojo-Domínguez A, GarcíaCordero J, Santos-Argumedo L, Cedillo-Barrón L, Arch. Virol. 155, 847-856, 2010. http://dx.doi.org/10.1007/ $\underline{\text { s00705-010-0652-x }}$

Peek LJ, Middaugh CR, Berkland C, Adv. Drug Deliv. Rev. 60, 915 928, 2008. http://dx.doi.org/10.1016/j.addr.2007.05.017

Pulendran B, Ahmed R, Nat. Immunol. 12, 509-517, 2011. http:// dx.doi.org/10.1038/ni.2039

Pumpens P, Grens E, Intervirology 44, 98-114, 2001. http://dx.doi. org $/ 10.1159 / 000050037$

Putnak JR, Coller BA, Voss G, Vaughn DW, Clements D, Peters I, Bignami G, Houng HS, Chen RC, Barvir DA, Seriwatana J, Cayphas S, Garçon N, Gheysen D, Kanesa-Thasan N, McDonell M, Humphreys T, Eckels KH, Prieels JP, Innis BL, Vaccine 23, 4442-4452, 2005. http://dx.doi.org/10.1016/j. vaccine.2005.03.042

Ramírez R, Falcón R, Izquierdo A, García A, Alvarez M, Pérez AB, Soto Y, Muné M, da Silva EM, Ortega O, Mohana-Borges R, Guzmán MG, Virus Genes 49, 185-195, 2014. http:// dx.doi.org/10.1007/s11262-014-1087-3

Rey FA, Heinz FX, Mandl C, Kunz C, Harrison SC, Nature 375, 291-298, 1995. http://dx.doi.org/10.1038/375291a0
Roehrig JT, Bolin RA, Kelly RG, Virology 246, 317-328, 1998. http:// dx.doi.org/10.1006/viro.1998.9200

Roehrig JT, Adv. Virus Res. 59, 141-175, 2003. http://dx.doi. org/10.1016/S0065-3527(03)59005-4

Simmons M, Murphy GS, Hayes CG, Am. J. Trop. Med. Hyg. 65, 159-161, 2001.

Sugrue RJ, Fu J, Howe J, Chan YC, J. Gen. Virol. 78, 1861-1866, 1997. http://dx.doi.org/10.1099/0022-1317-78-8-1861

Suzarte E, Marcos E, Gil L, Valdés I, Lazo L, Ramos Y, Pérez Y, Falcón V, Romero Y, Guzmán MG, González S, Kourí J, Guillén G, Hermida L, Arch. Virol. 159, 1629-1640, 2014. http://dx.doi.org/10.1007/s00705-013-1956-4

Taylor DN, Treanor JJ, Strout C, Johnson C, Fitzgerald T, Kavita U, Ozer K, Tussey L, Shaw A, Vaccine 29, 4897-4902, 2011. http://dx.doi.org/10.1016/j.vaccine.2011.05.001

Treanor JJ, Taylor DN, Tussey L, Hay C, Nolan C, Fitzgerald T, Liu G, Kavita U, Song L, Dark I, Shaw A, Vaccine 28, 8268-8274, 2010. http://dx.doi.org/10.1016/j.vaccine.2010.10.009

Valdés I, Hermida L, Martín J, Menéndez T, Gil L, Lazo L, Castro J, Niebla O, López C, Bernardo L, Sánchez J, Romero Y, Martínez R, Guzmán MG, Guillén G, Vaccine 27, 995-1001, 2009a. http://dx.doi.org/10.1016/j.vaccine.2008.11.106

Valdés I, Bernardo L, Gil L, Pavón A, Lazo L, López C, Romero Y, Menendez I, Falcón V, Betancourt L, Martín J, Chinea G, Silva R, Guzmán MG, Guillén G, Hermida L, Virology 394, 249-258, 2009b. http://dx.doi.org/10.1016/j. virol.2009.08.029

Valdés I, Hermida L, Gil L, Lazo L, Castro J, Martín J, Bernardo L, López C, Niebla O, Menéndez T, Romero Y, Sánchez J, Guzmán MG, Guillén G, Int. J. Infect. Dis. 14, e377-383, 2010. http://dx.doi.org/10.1016/j.ijid.2009.06.017

Valdés I, Gil L, Romero Y, Castro J, Puente P, Lazo L, Marcos E, Guzmán MG, Guillén G, Hermida L, Clin. Vaccine Immunol. 18, 455-459, 2011. http://dx.doi.org/10.1128/ CVI.00382-10

Villar L, Dayan GH, Arredondo-García JL, Rivera DM, Cunha R, Deseda C, Reynales H, Costa MS, Morales-Ramírez JO, Carrasquilla G, Rey LC, Dietze R, Luz K, Rivas E, Miranda Montoya MC, Cortés Supelano M, Zambrano B, Langevin E, Boaz M, Tornieporth N, Saville M, Noriega F; CYD15 Study Group, N. Engl. J. Med. 372, 113-123, 2015. http:// dx.doi.org/10.1056/NEJMoa1411037

Wan SW, Lin CF, Chen MC, Lei HY, Liu HS, Yeh TM, Liu CC, Lin YS, Am. J. Infect. Dis. 4, 85-91, 2008. http://dx.doi. org/10.3844/ajidsp.2008.85.91

Webster DP, Farrar J, Rowland-Jones S, Lancet Infect. Dis. 9, 678-687, 2009. http://dx.doi.org/10.1016/S1473-3099(09)70254-3

Weiskopf D, Sette A, Front. Immunol. 5, 93, 2014. http://dx.doi. org/10.3389/fimmu.2014.00093

World Health Organization (2009): Dengue Guidelines for Diagnosis, Treatment, Prevention, and Control. http://www. who.int/rpc/guidelines/9789241547871/ en/. Accessed 10 March 2015.

Yauch LE, Zellweger RM, Kotturi MF, Qutubuddin A, Sidney J, Peters B, Prestwood TR, Sette A, Shresta S, J. Immunol. 182, 4865-4873, 2009. http://dx.doi.org/10.4049/jimmunol.0801974 
Yauch LE, Prestwood TR, May MM, Morar MM, Zellweger RM, Peters B, Sette A, Shresta S, J. Immunol. 185, 5405-5416, 2010. http://dx.doi.org/10.4049/jimmunol.1001709

Zellweger RM, Miller R, Eddy WE, White LJ, Johnston RE, Shresta S, PLoS Pathog. 9, e1003723, 2013. http://dx.doi. org/10.1371/journal.ppat.1003723

Zhang S, Liang M, Gu W, Li C, Miao F, Wang X, Jin C, Zhang L, Zhang F, Zhang Q, Jiang L, Li M, Li D, Virol. J. 8, 333, 2011. http://dx.doi.org/10.1186/1743-422X-8-333

Zhang Y, Zhang W, Ogata S, Clements D, Strauss JH, Baker TS, Kuhn RJ, Rossmann MG, Structure 12, 1607-1618, 2004. http://dx.doi.org/10.1016/j.str.2004.06.019
Zhang ZS, Weng YW, Huang HL, Zhang JM, Yan YS, Mol. Med. Rep. 11, 1009-1016, 2015.

Zhao H, Jiang T, Zhou XZ, Deng YQ, Li XF, Chen SP, Zhu SY, Zhou X, Qin ED, Qin CF, PLoS One 9, e86573, 2014. http:// dx.doi.org/10.1371/journal.pone.0086573

Zuest R, Valdes I, Skibinski D, Lin Y, Toh YX, Chan K, Hermida L, Connolly J, Guillen G, Fink K, Vaccine 33, 1474-1482, 2015. http://dx.doi.org/10.1016/j.vaccine.2015.01.074

Zulueta A, Martín J, Hermida L, Alvarez M, Valdés I, Prado I, Chinea G, Rosario D, Guillén G, Guzmán MG, Virus Res. 121, 65-73, 2006. http://dx.doi.org/10.1016/j. virusres.2006.04.003 